\title{
A Review for Southern Highbush Blueberry Alternative Production Systems
}

\author{
Yang Fang ${ }^{1}$, Gerardo H. Nunez ${ }^{1}{ }^{\oplus}$, Mariana Neves da Silva ${ }^{1}$, Douglas A. Phillips ${ }^{2}$ and \\ Patricio R. Munoz ${ }^{1, * \text { (D) }}$ \\ 1 Horticultural Sciences Department, University of Florida/IFAS, Gainesville, FL 32611, USA; \\ yangfang@ufl.edu (Y.F.); g.nunez@ufl.edu (G.H.N.); mnevesdasilva@ufl.edu (M.N.d.S.) \\ 2 Gulf Coast Research and Education Center, University of Florida, Wimauma, FL 33598, USA; \\ dal64372@ufl.edu \\ * Correspondence: p.munoz@ufl.edu
}

Received: 21 August 2020; Accepted: 2 October 2020; Published: 9 October 2020

\begin{abstract}
Southern highbush blueberry cultivation has expanded into non-traditional growing areas worldwide due to elite cultivars and improved horticultural practices. This article presents a comprehensive review of current production systems-alternatives to traditional open field production-such as production in protected environments, high-density plantings, evergreen production, and container-based production. We discuss the advantages and disadvantages of each system and compare their differences to open field production. In addition, we provide potential solutions for some of the disadvantages. We also highlight some of the gaps existing between academic studies and production in industry, providing a guide for future academic research. All these alternative systems have shown the potential to produce high yields with high-quality berries. Alternative systems, compared to field production, require higher establishment investments and thus create an entry barrier for new producers. Nevertheless, with their advantages, alternative productions have the potential to be profitable.
\end{abstract}

Keywords: Vaccinium corymbosum interspecific hybrids; high tunnel; greenhouse; plant factory; non-dormant; substrate; container; evergreen; high density

\section{Introduction}

Blueberry (Vaccinium spp. section cyanococcus) consumption has dramatically increased globally over the last 5 years [1]. North America is a traditional market where approximately $58 \%$ of all fresh blueberries are consumed [1]. Demand has rapidly increased in new markets, such as Europe and China. This rising demand has been accompanied by increased production in both traditional and new growing areas around the world. Southern highbush blueberry (SHB, Vaccinium corymbosum L. interspecific hybrids) has been instrumental to this expansion due to its high fruit quality for fresh markets and adaptation to subtropical and tropical production areas.

New cultivars and innovative horticultural practices have enabled profitable SHB cultivation in areas where temperate crops were not common two decades ago [2,3], including parts of South Africa, Spain, Morocco, Mexico, Chile, China, Peru, and Argentina. Alternative production systems combine protected agriculture practices (climate control, precise irrigation, and fertilization) and specialized canopy management to increase input use efficiency and shorten plant juvenility. This increases total productivity and can reduce the period of negative cash flow [3,4].

In this comprehensive review, we summarize peer-reviewed literature published from 1987 to April 2020 and accessed through Google Scholar. Four main themes emerged among the alternative production systems used to cultivate SHB: (a) production in protected environments such as high 
tunnels, greenhouses, and factories; (b) high-density planting production; (c) evergreen production; and (d) container-based production. These production systems can either be used together (Figure 1) or independently (Figure 2), according to the economic and environmental factors in each region. Where knowledge gaps in SHB cultivation exist, we used publications from northern highbush blueberry (NHB, V. corymbosum), rabbiteye blueberry (V. virgatum), and other crops such as tomato (Solanum lycopersicon), raspberry (Rubus idaeus), and strawberry (Fragaria ananassa).

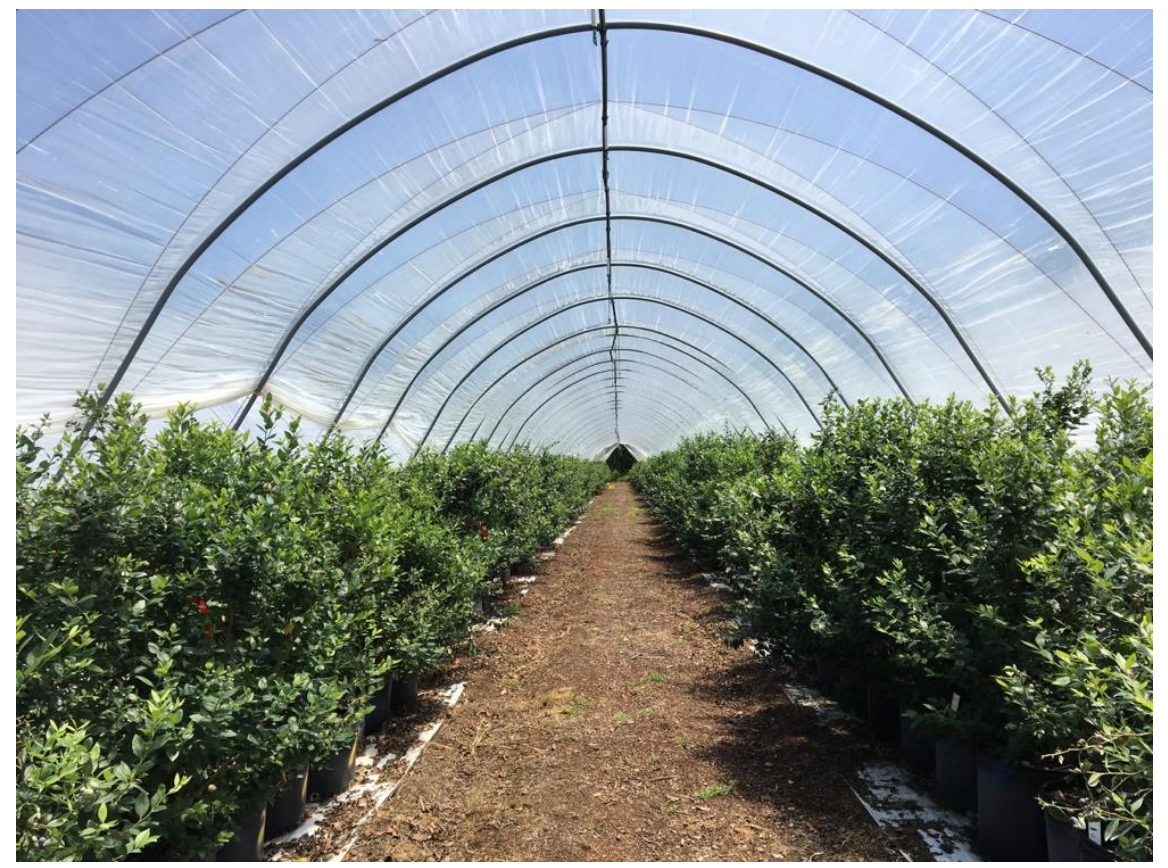

Figure 1. Southern highbush blueberry planted in a combination of alternative production systems including high tunnel, high density (10976 plants per hectare), evergreen, and containerized soilless substrate production systems in north Florida.

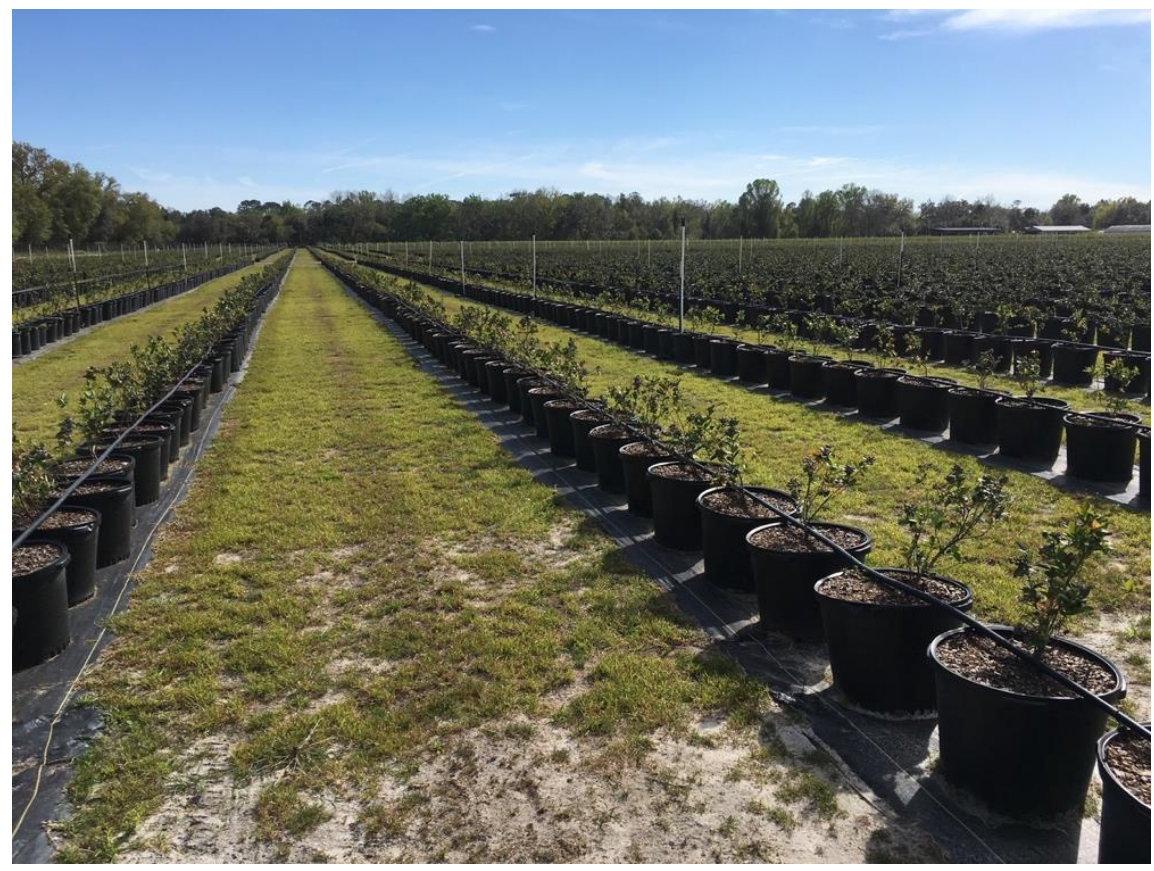

Figure 2. Southern highbush blueberry containerized soilless substrate production with 5434 plants per hectare in south Florida. 


\section{Protected Environments}

\subsection{High Tunnel Production}

High tunnel production has become popular among raspberry, blackberry, and strawberry producers [5-7]. The mesoclimate inside high tunnels has been shown to accelerate bloom, expedite fruit ripening, increase yields, improve berry quality, extend the harvest season, and decrease berry losses to rain and frost $[2,5,6,8-10]$.

Southern highbush blueberry production in unheated high tunnels (Figure 3) has been studied in different countries, including Japan [11], Spain [12], Portugal [13], Chile [2], and the United States [14]. High tunnels increase soil and air temperature around the plant $[6,15,16]$, reducing cold stress or damage [16] and enhancing heat unit accumulation during winter and early spring $[11,14,16,17]$. Warmer temperatures during the cold parts of the season are widely accepted as the reason for earlier fruit ripening in high tunnels $[11,14,16,17]$. For example, the SHB cultivars 'Snowchaser', 'Emerald', 'Jewel', and ' $\mathrm{O}$ 'Neal' grown in high tunnels were ready to harvest nearly a month earlier than the same cultivars grown in open field conditions $[14,16,18]$. High tunnels have supported the northward expansion of SHB cultivation, for example, within the United States to areas in Mississippi where only rabbiteye blueberries were previously cultivated [19]. Additionally, the use of high tunnels can significantly reduce water usage for freeze protection, requiring only one-tenth of the total volume used in the open field [16].

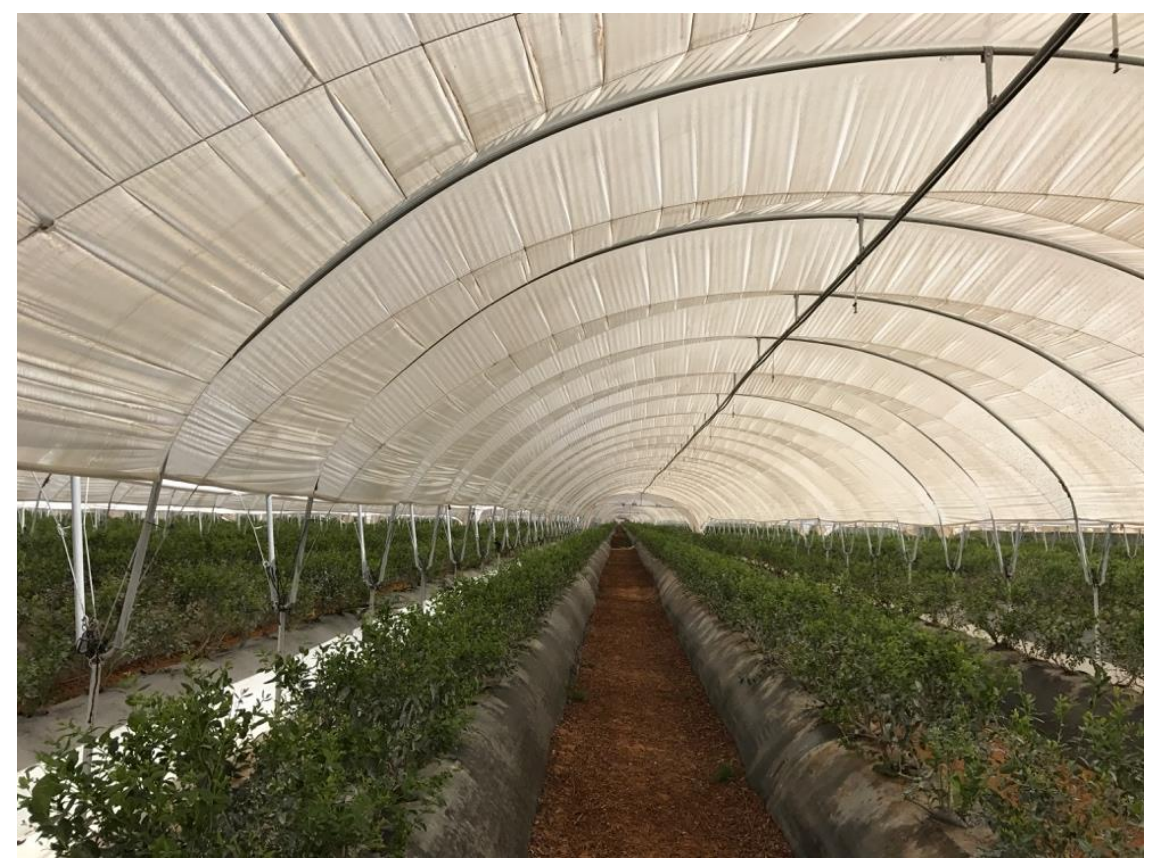

Figure 3. Southern highbush blueberry in a high tunnel production system.

While temperature increases during winter and early spring enhance SHB growth, air and soil temperatures inside high tunnels can quickly surpass plant optimal temperatures during late spring and summer. Air temperatures above $30^{\circ} \mathrm{C}$ reduce photosynthetic rates in blueberry [20]. Additionally, warm night temperatures $\left(21^{\circ} \mathrm{C}\right)$ can decrease fruit set [21]. Optimal temperature ranges vary among SHB cultivars, and cultivars with a recent introgression of subtropical wild species might exhibit greater tolerance for high temperatures [22]. Late-developing cultivars might be negatively impacted by high air temperatures inside high tunnels, where poor fruit set could reduce productivity [13].

High tunnels are passively heated and cooled structures. Thus, temperature regulation inside high tunnels relies on ventilation and radiation. Tunnels are commonly ventilated as soon as air 
temperatures reach around $10{ }^{\circ} \mathrm{C}$. This is a labor-intensive practice in the absence of automated roll-up sidewalls. Conversely, higher temperatures in high tunnels may be insufficient for freeze protection during the winter or early spring in the absence of automatic heating systems [23]. Radiative cooling inside high tunnels varies with the weather (cloudy day vs. clear day) and type of plastic covering material. For example, long-wave-blocking plastic can retain more heat [14,23]. In addition, high tunnels reduce the exchange of convective heat with the surrounding air, and thus, the cooling impact from pine bark beds (if used) may have more negative effects on the plant-level temperature compared to the effects of bark bed in the open field [24]. Therefore, where temperatures drop below $1{ }^{\circ} \mathrm{C}$, growers use micro-sprinklers to increase air humidity inside the tunnel and provide additional freeze protection [16].

Closed, warm high tunnels during early spring may be a challenge for some pollinators. The foraging activities of European honeybees (Apis mellifera Linnaeus) peak at $20^{\circ} \mathrm{C}$ [25]. Thus, the mesoclimate inside high tunnels might affect the performance of this common blueberry pollinator. Insufficient pollination may cause a lower average fruit set inside high tunnels than in open fields [11,26]. Roll-up sidewalls can be used to create optimal temperatures and improve pollinator access during the day. Alternatively, bumble bees (Bombus impatiens Cresson) could be brought inside the tunnels. Where native pollinators are abundant, they willingly venture into the protected structure [8]. Considering that SHB cultivars differ in their ability to self-pollinate [27], long-term solutions to poor pollination inside high tunnels may include using cultivars with better self-fertility or a tendency to produce parthenocarpic fruit. Additionally, the plant growth regulator gibberellic acid $\left(\mathrm{GA}_{3}\right)$ could be investigated in SHB. The recommendation of spraying $\mathrm{GA}_{3}$ in the literature is limited to rabbiteye blueberry, where the use of $\mathrm{GA}_{3}$ has been reported to cause small and late ripening berries $[21,28]$.

\subsection{Greenhouse and Plant Factory (Growth Chamber) Production}

In contrast to high tunnel production, environmental conditions such as temperature, humidity, light, and $\mathrm{CO}_{2}$ concentrations can be controlled in greenhouses and plant factories (closed growing systems similar to growth chambers), making it possible to produce fruit year-round, especially in plant factories [29].

In the current literature, most SHB research in greenhouse or plant factory conditions is focused on investigating plant growth, photosynthetic ability, and fruit quality by adjusting the photoperiod, temperature, humidity, and other environmental factors [29-32]. Studies exploring the potential yield in greenhouse production is limited to a study conducted by Motomura et al. [33] in Volcano, Hawaii. They evaluated a key greenhouse production component, pot size, without controlling environmental parameters. However, there are many factors to consider in this system, including temperature, relative humidity, light quality, and photoperiod. Hence, there is a lack of research on optimizing management practices to maximize SHB yield in greenhouse or plant factory production. Controlling temperature is more feasible in plant factories than in greenhouses [29,30,34,35]. Spann et al. [35] compared plant growth under 28 and $21^{\circ} \mathrm{C}$ and discovered that flower bud initiation and whole-plant carbohydrate concentration was significantly reduced at $28^{\circ} \mathrm{C}$. Aung et al. [30] found that the optimal temperature for SHB cultivars 'Misty' and 'Sharpeblue' should be around $15^{\circ} \mathrm{C}$ during dark periods and $25^{\circ} \mathrm{C}$ in light periods, which agrees with Kameari et al. [34] and Cho et al. [29]. The experiments on SHB cultivars 'Misty' and 'Sharpeblue' showed that relative humidity above $40 \%$ can avoid stomatal closure under low humidity and below $80 \%$ can reduce disease pressure under high humidity [29,30]. Artificial lighting can be used to supplement sunlight in order to extend the photoperiod in the greenhouse or as an exclusive light source for a plant factory. Different cultivars had varying reactions to natural sunlight and artificial light, but photosynthetic rates under artificial light were found to be more constant [30]. Although photosynthetic rates increase with light intensity from 0 to $1000 \mu \mathrm{mol} . \mathrm{m}^{-2} \cdot \mathrm{s}^{-1}$, temperature also increases with light intensity, and thus, more energy is consumed [30]. High-pressure sodium lamps or light-emitting diode (LED) lights at an intensity of 300 to $500 \mu \mathrm{mol} . \mathrm{m}^{-2} . \mathrm{s}^{-1}$, or at even lower light intensities of 150 to $350 \mu \mathrm{mol} . \mathrm{m}^{-2} . \mathrm{s}^{-1}$, have been reported to provide enough radiation for 
sufficient photosynthesis and plant growth [29-31]. Light quality is able to induce different responses in blueberry flowering characteristics, with blue light (approximately $450 \mathrm{~nm}$ ) advancing flowering and red light (approximately 630-660 nm) delaying flowering. SHB cultivars 'Misty' and 'Sharpeblue' exhibited earlier and more abundant flowering under half blue and half red LED lights during flower bud differentiation (FBD) than plants under sole blue, sole red, or artificial white light [29]. There are conflicting reports on the photoperiod required to promote SHB flowering. According to Spann et al. [31,35], flower bud initiation (FBI) in SHB is a short day (long night) phytochrome-mediated response, and thus, no flower buds were observed under a 16-hr photoperiod in their study. Once flower buds are initiated, the differentiation of flower buds can be enhanced under long days [31,35]. However, Cho et al. [29] set a 14-hr photoperiod during FBI and a 10-hr photoperiod during FBD and reported flowers. Each of these studies used the same SHB cultivars, 'Misty' and 'Sharpeblue', and the inconsistent results may be due to the use of shorter long-day settings in Cho et al. [29] or different temperatures in Spann et al. [31,35].

\section{High-Density Planting Production}

Southern highbush blueberry is traditionally planted with 2.75 to $3.00 \mathrm{~m}$ between beds and $0.76 \mathrm{~m}$ to $0.9 \mathrm{~m}$ between bushes within the row. This spacing leads to plant densities between 3587 and 4323 plants per hectare [36]. There is great interest in increasing SHB planting densities to optimize space use inside high tunnels, bird nets, and other protective structures. Previous studies have investigated increasing plant densities by reducing plant spacing to 1.5 to $0.45 \mathrm{~m}$ (equivalent to from 2154 to 7173 plants/ha) or planting two rows of plants per planting bed with spacing of 0.75 and $0.45 \mathrm{~m}$ between plants (equivalent to 7173 and 11854 plants/ha) [36-38]. In these studies, spacing between beds was typically $3 \mathrm{~m}$. Commercial growers with container production in some cases have increased single row planting density by reducing across-bed spacing. Although close spacing may reduce yield and/or biomass per plant, overall yield and/or biomass per hectare increases due to the larger plant population [38,39]. For example, when plant spacing was reduced from 1.2 to $0.45 \mathrm{~m}$, cumulative yield doubled from year 3 to year 7 [37]. Similarly, planting in double row beds as opposed to single row beds led to higher yield per area unit [36]. Notably, higher planting densities do not seem to reduce berry weight or size [36,37].

A critical advantage of high-density plantings is that they can reduce the time required for a field to reach positive cash flows. While there is no evidence to suggest that the development of each individual plant is accelerated, large populations of small plants can attain significant yields. SHB cultivation systems have high establishment costs $[40,41]$. Thus, the profit potential of growing blueberries can be enhanced by increasing productivity in the early years of production [42]. High-density SHB plantations can reach peak commercial yields in less than 4 years [39].

While high-density plantations might increase water and fertilizer use efficiency and improve weed control [38], high plant densities can create new challenges in SHB management. High-density plantations might be more sensitive to drought stress due to increased competition between plants for water [37]. Additionally, high-density plantings might restrict light penetration into the plant canopy [43], affecting photosynthesis and other light-dependent responses. Cultivar choice and/or light reflection could be used to improve light penetration. SHB canopy architecture ranges from upright to spreading [44,45]. Varieties with upright growth such as 'Abundance', 'Chickadee', and 'Meadowlark' might be better suited to high-density plantings than those with a spreading growth habit. Alternatively, reflective plastic mulches can be used to increase photosynthetically active radiation in the lower parts of the canopy [46], improving photosynthetic rates and increasing fruit quality [46-48]. High-density plantations inside high tunnels have the advantage that plastic glazing diffuses sunlight, improving light distribution through the canopy [49].

Canopy management in high-density plantations can also be challenging. Based on the estimation of Strik and Buller [37], it takes at least 37\% more time to prune NHB plants with $0.45 \mathrm{~m}$ in-row spacing than those with $1.2 \mathrm{~m}$. Additionally, leaf disease incidence can be aggravated because of the environment 
created by warmer temperatures and higher humidity due to plant transpiration, restricted outside air exchange, and lower airflow between plants in a high-density environment [36,38,50]. Fungal foliar diseases can develop under these conditions, such as anthracnose, Septoria leaf spot, target spot, and rust among others, typically requiring fungicide applications for control [51]. Cultural practices to help minimize disease include using disease-resistant varieties, maintaining a pest-free environment to mitigate the transmission of insect vectored pathogens, weed control to eliminate alternate disease hosts, and sanitation practices to avoid disease arrival and spread [52]. A high-density environment may also limit effective pesticide spray application. As canopy density increases, spray coverage and uniformity can decrease. This is especially problematic for nonsystemic fungicides and insecticides for certain pathogens and pests [53].

\section{Evergreen Production}

Southern highbush blueberry can be grown as an evergreen because of its tropical and subtropical parental species [54]. Evergreen blueberry production focuses on preventing defoliation during the colder periods of the year by managing winter temperatures, fertilization, pests, and diseases $[51,55,56]$. A full canopy of healthy leaves for at least the last $70 \%$ of the flowering-to-ripening interval is a prerequisite for producing high yields of high-quality berries early in the season [57]. This production system is only feasible in areas with light or no winter freezes, or under high tunnels [55-57]. Evergreen blueberry production has rapidly expanded in the United States (California, Florida, and Hawaii) as well as some parts in Australia, Spain, China, Argentina, Mexico, and Morocco [2,58-61] because evergreen plants can be managed to produce berries all year long or to target high-value market windows $[2,59]$.

There are management and physiological differences between deciduous and evergreen SHB production systems (Figure 4). While in deciduous systems fertilization ramps down during fall and winter [62], in evergreen systems, nitrogen $(\mathrm{N})$ application continues throughout the season [63]. Nitrogen fertilization and the maintenance of healthy canopy promote high photosynthetic rates and carbohydrate synthesis at a time when deciduous SHB consumes its carbohydrate reserves $[55,63]$. Carbohydrate availability might be the reason for the shorter period between flower bud initiation and floral budbreak for evergreen compared with deciduous SHB [63]. This plant response can be managed to accomplish early harvests (Figure 5).

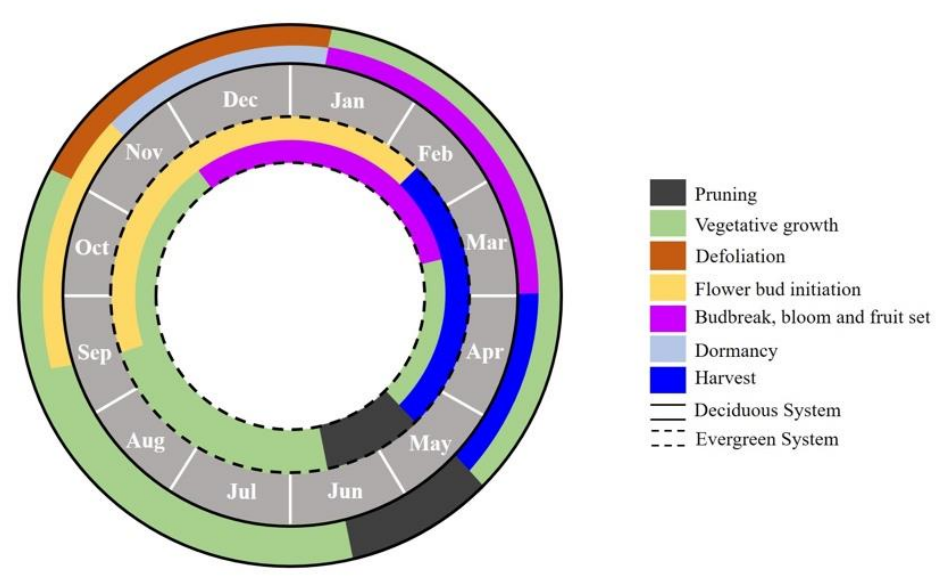

Figure 4. Timing comparison of the different stages of fruit production for southern highbush blueberry under an evergreen production system (inner ring) and a deciduous production system (outer ring) in Florida. 

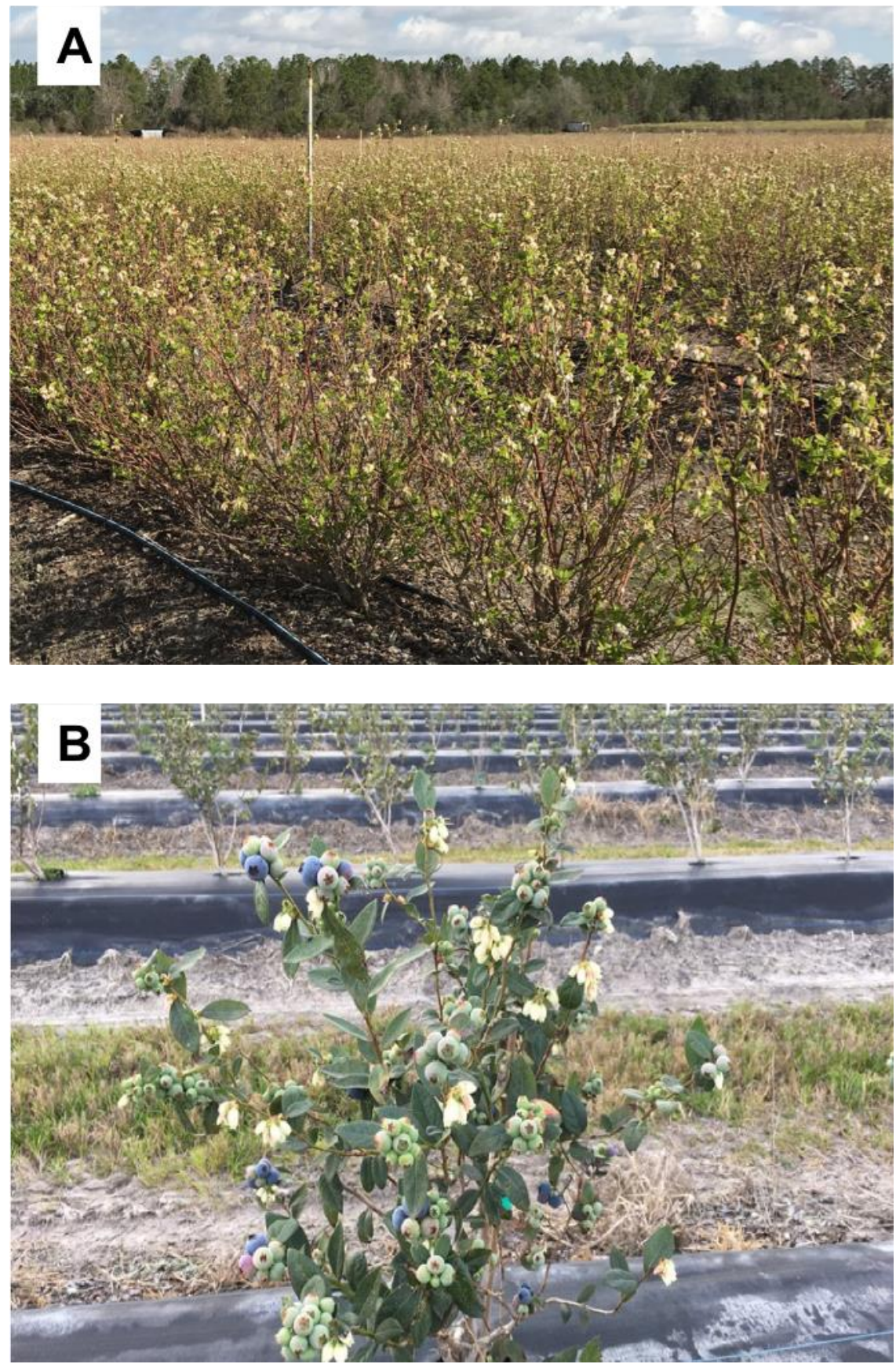

Figure 5. Southern highbush blueberry plants in February 2018 flowering in deciduous system (A), while carrying ripe berries in evergreen system $(\mathbf{B})$.

The presence of leaves in evergreen SHB might also cause other responses. Since leaves are the organ where photoperiod perception takes place [64], leaf retention extends short-day perception and flower bud initiation into the winter (Figure 4) $[63,65,66]$. Protracted flower bud initiation not only increases flower bud number but also lengthens the harvest season [55]. High flower bud density and fruit number decrease reserve carbohydrates. Any additional available carbohydrate tends to be used for new flower bud initiation rather than increasing cell division. So, vegetative growth as well as fruit size and quality can be negatively affected [55,67]. Fruit thinning can be used where concentrated production is important for mechanization or to meet market demands [55]. Both fruit and flower thinning can reduce fruit numbers and improve fruit size, but given the continuous flower bud initiation in evergreen SHB, flower removal is less effective at ameliorating sink competition [55]. 
There are several open questions regarding fertilization for evergreen production. Unlike in the deciduous system, in evergreen SHB, flower bud break and vegetative growth coincide in time with increasing sink competition. Thus, the ideal fertilizer rate for evergreen SHB should sustain both vegetative and reproductive growth. Reeder et al. [65] tested three $\mathrm{N}$ rates: 84 (equivalent to $0.215 \mathrm{~g} / \mathrm{plant} /$ week), 168 , or $252 \mathrm{~kg} / \mathrm{ha} / \mathrm{yr}$ in year 1, and 168, 252, or $336 \mathrm{~kg} / \mathrm{ha} / \mathrm{yr}$ in year 2 for evergreen SHB production in Florida with the rate of $\mathrm{N}$, phosphorus $(\mathrm{P})(0.039 \mathrm{~g} / \mathrm{plant} /$ week $)$, and potassium $(\mathrm{K})$ $(0.155 \mathrm{~g} / \mathrm{plant} /$ week) reduced by half during the period from December to March. They found that applications of up to $252 \mathrm{~kg} \mathrm{~N} / \mathrm{ha} / \mathrm{yr}$ increased plant canopy volume and leaf retention and advanced vegetative bud break, but there seemed to be no effect on yield. A study on rabbiteye blueberry [68] showed a negative impact of $\mathrm{P}$ application on shoot growth during the dormant season. There is a lack of research on exploring the effect of $\mathrm{P}$ and $\mathrm{K}$ rates, the N:P:K ratio, and/or micronutrient concentrations during flower and fruit development stages on yield and berry quality.

A slightly different evergreen system is used in regions with none to mild winters and very low latitudes such as Peru, Colombia, and Mexico. In these settings, SHB cultivars can initiate flower buds and produce berries on first-year canes during the entire year. This allows growers to time berry production by regulating pruning timing and severity. For example, growers in Jalisco, Mexico, prune in October and harvest 6 months later. Similarly, in Trujillo, Peru, growers prune in February to accomplish berry production from September to November. However, the time from pruning to production still depends on the cultivar being used that can range from 5 to 8 months. Berries produced on first-year canes tend to be large, but in some cultivars, they can have poor fruit quality due to large picking scars and petal retention. At this time, there is a lack of peer-reviewed research describing or improving this production system, because the research is being carried by industry.

\section{Container-Based Production}

Southern highbush blueberry is most productive in soils with low $\mathrm{pH}$ and high organic matter content [4]. Agricultural soils rarely meet these requirements. Thus, growers traditionally prepare fields with the addition of sulfur, organic matter, or other amendments [69-71]. Even with these inputs, SHB soil preferences limit the areas where it can be planted. Recently, containerized SHB production has gained popularity, as the use of soilless substrates makes it possible to produce in a broader range of soils. Soilless substrates allow the precise control of nutrient concentrations in the rhizosphere and allow culturing on land with serious soil problems such as soil-borne pests, soil salinity, infertile soil, and chemical residues in soil $[72,73]$. Container-based production also allows growers to move and adjust plant spacing based on growth $[72,74]$. There are several factors to consider for this production system.

Container size and shape must be carefully selected. Research on the optimum container size for blueberry production is limited. Whidden [74] reported that 56 to $95 \mathrm{~L}$ was the container size commonly used in commercial blueberry production in central Florida. Studies using container sizes within this range reported first-year yields ranging from $0.9 \mathrm{~kg} / \mathrm{plant}$ to more than $2 \mathrm{~kg} / \mathrm{plant}$ based on different cultivars and fertilizer rates $[19,75]$. Containers smaller than $38 \mathrm{~L}$ have been shown to negatively affect yields [33]. Nevertheless, considering the diversity in SHB plant shape and vigor, it is conceivable that smaller and larger container sizes might be suitable for commercial cultivation depending on the cultivar used. An additional challenge for cultivation in smaller containers is plant anchorage. Under high wind conditions, plants in smaller containers might blow over, requiring trellising or other anchorage mechanisms (Figure 6) [74,76]. In addition, where high planting density is a goal, container size will affect the maximum potential planting density. 


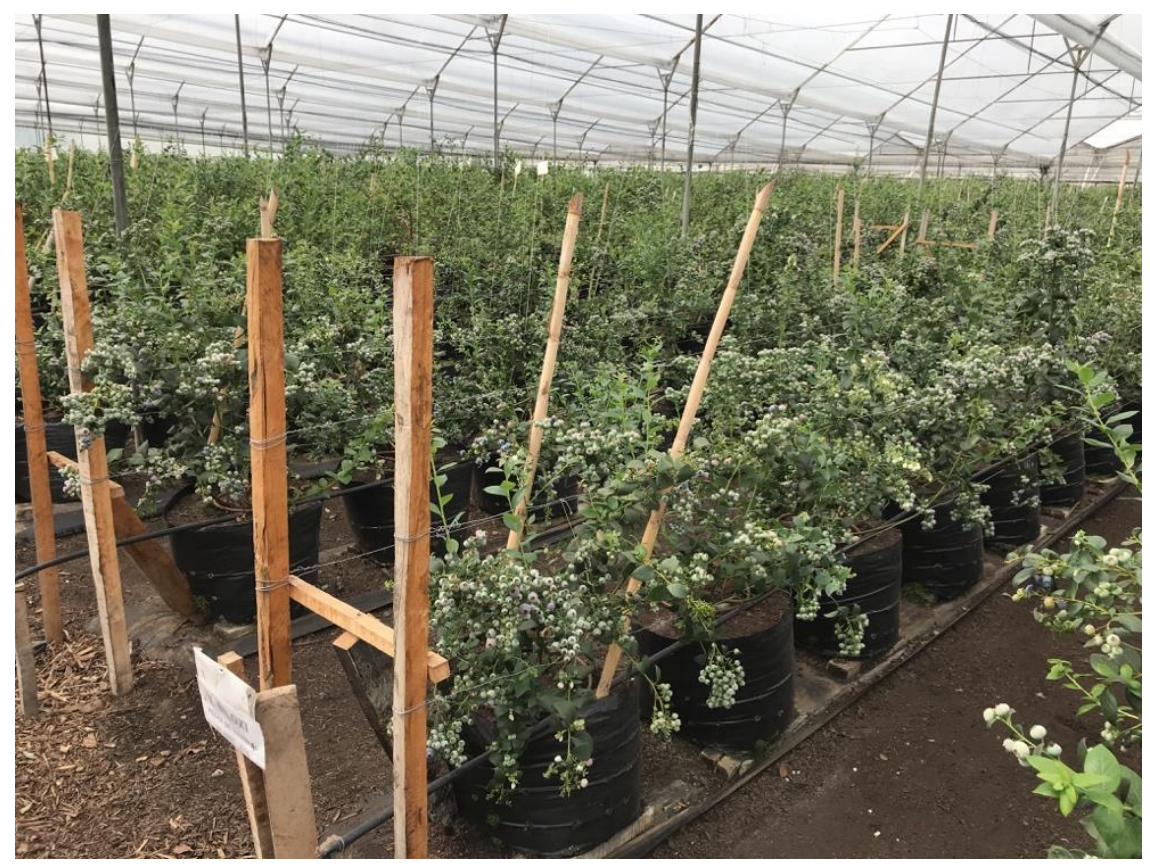

Figure 6. Example of trellis for plant anchorage used in container-based production system for southern highbush blueberry.

Plants growing in containers has restricted space for root growth, unlike those grown in traditional field environments [74]. Reduced rooting volume can result in physiological and morphological changes, affecting root and shoot growth, photosynthesis, nutrient uptake, root respiration, flowering, and biomass accumulation and partitioning (reviewed by Poorter et al. [77]). As container size increases, shoot and root biomass generally increase [78]. At a given volume, the height of the container has a positive effect on the free-draining water content [79]. Shorter containers tend to have less water suction at the surface, which leads to larger pores in the substrate that would then fill with water [79], causing a higher risk of hypoxia for plant roots. However, with increasing container height, water is less evenly distributed from the surface to the bottom [80]. Unequal water distribution and temperature fluctuation inside the container results in unevenly distributed root systems [77]. Additionally, media pore space gradually decreases as roots occupy more space in the pot, which negatively affects both the water-holding capacity and aeration [81].

Sphagnum peat moss, coconut coir, and perlite are commonly used for container-based blueberry production. Peat moss is widely used for SHB rooting and germination in nurseries [82-84] due to its low native $\mathrm{pH}$ and high water-holding capacity. Coconut coir (also called coconut fiber or coconut pith) is a biodegradable substrate that also contributes high water-holding capacity to substrate mixes. Perlite is an inorganic material that is not greatly affected by acids or microorganisms [85]. However, when $\mathrm{pH}$ is low, perlite can release toxic aluminum (Al) into the root zone [85]. Given their relative strengths and weaknesses, these materials are commonly combined in custom mixes. Recent studies have focused on media composition for blueberry production [86,87]. Media composed of $60 \%$ or more peat or coconut coir enhance vegetative growth in SHB [86]. However, there is evidence that some SHB cultivars might perform better in peat-based rather than coconut coir-based media [87]. Perlite content seems to only affect substrate-water relations [87]. In areas where tree barks are available and affordable, this material has also been used to improve media aeration [88,89].

To date, there are several open questions regarding substrate choice for container-based production. As the first plantations come of age, research should emphasize substrate longevity and its impact on productivity. The decomposition of organic materials can cause substrate compaction and shrinkage, which affects aeration and water distribution in the container. This might be particularly pressing for substrates with high pine bark contents, as this material traditionally has a high carbon to nitrogen 
ratio. Another area of interest is the impact of substrate choice on reproductive growth and fruit quality. Studies on strawberry and tomato indicate that substrate composition can affect yield and fruit characteristics such as firmness, total soluble solids, titratable acidity, and the content of phenolic compounds [90,91], but no published study currently exists for blueberry.

Watering systems commonly used in container-based blueberry production are drip and overhead irrigation [74]. Drip tapes and drip emitters are the main tools for the irrigation and fertigation in this system. Overhead irrigation is usually used as a supplement to reduce canopy air temperature in summer or provide freeze protection in the winter. Drip tape can be laid over the row of containers, usually with two tapes per container. Where emitters are used, better water distribution can be achieved by increasing the number of emitters per container, with four emitters per container commonly seen in commercial plantings around the globe. In container-based systems, both an excess and lack of water are possible due to the low rooting volume and lack of access to subsurface water. Thus, irrigation rates must be dynamically adjusted according to plant growth and environmental conditions. In ornamental or vegetable container production [92,93], growers schedule the timing and duration of irrigation events according to substrate matric potential. However, research is lacking to facilitate this practice in blueberry. Instead, irrigation rates are generally adjusted based on drainage volume [72,86]. The target leaching fraction (the ratio of drainage to the applied water) should typically be between $15 \%$ and $25 \%[72,86]$.

In container-based blueberry production, mineral nutrients are delivered through fertigation or granular fertilizers. Optimum $\mathrm{N}$ rates are cultivar dependent. For example, optimum yields in SHB cultivar 'Star' in $95 \mathrm{~L}$ containers are attained with $30.0 \mathrm{~g} \mathrm{~N} /$ plant/year, while cultivar 'Misty' had the highest yield with $20.1 \mathrm{~g} \mathrm{~N} /$ plant/year, when three rates were tested: 10.5, 20.1, and $30.0 \mathrm{~g}$ $\mathrm{N} /$ plant/year [75]. Applications up to $36 \mathrm{~g} \mathrm{~N} /$ plant/year have been reported in $56 \mathrm{~L}$ containers [19], but the use of such a high $\mathrm{N}$ rate was probably due to the use of a slow-release fertilizer. Additionally, Wilber and Williamson [75] compared applications of $12 \mathrm{~N}-1.8 \mathrm{P}-6.6 \mathrm{~K}$ and $12 \mathrm{~N}-5.2 \mathrm{P}-9.9 \mathrm{~K}$ and found that the additional $\mathrm{P}$ and $\mathrm{K}$ did not affect vegetative or reproductive growth. Additional research is necessary to determine optimum nutrient application rates and timing for container-based blueberry production. Previous research has documented heterogeneous nutrient content in soilless media [94] and the effects of media on nutrient uptake $[86,87]$. Further, fertility recommendations for soil-based production might not cross over appropriately to container-based systems.

\section{Conclusions}

Southern highbush blueberry was once a regional crop in the United States, but now, it is a specialty crop cultivated throughout the world. This expansion in the crop's range has been fueled by increasing demand for blueberries worldwide, the availability of versatile cultivars, and the adoption of new, intensive production systems. Compared to the field production, all alternative systems detailed in this paper require higher investments. Structures, glazing, temperature control, and irrigation equipment represent additional fixed costs. Plants, containers, soilless substrates, fertilizers, and pest control are in variable costs that will depend on planting density. Ultimately, establishment costs can be as high as $\$ 120,000$ per hectare, excluding land cost [1]. While this high establishment cost constitutes a barrier for entry, initial investments can be justified by higher yields per acreage, commercial yields in the early years of production, and/or adjusting the harvest season to meet market windows with high fruit prices. Intensive systems that combine container-based, high-density planting inside high tunnels can be profitable in some markets [95].

To date, research focusing on these production systems is still in its infancy. While there is a growing body of literature focusing on system design, there is a lack of research focusing on system operation. The reassessment of fertilization, pruning, and pest management recommendations is imperative to help growers close the gap between investment and profits. Additionally, it is important for the deep and diverse gene pool in SHB breeding programs to be exploited to develop cultivars that are specifically well-suited for cultivation under alternative systems. Finally, alternative blueberry 
production systems could also benefit from the incorporation of cutting-edge technologies such as solid set canopy delivery [96] and automated irrigation scheduling [97]. Together, these innovations can position blueberry production at the forefront of horticultural technology.

Author Contributions: Conceptualization, Y.F. and P.R.M.; writing-original draft preparation, Y.F., M.N.d.S. and D.A.P.; writing—review and editing, G.H.N., D.A.P., Y.F., M.N.d.S. and P.R.M.; visualization, M.N.d.S., Y.F., D.A.P., G.H.N., P.R.M.; supervision, P.R.M.; All authors have read and agreed to the published version of the manuscript.

Funding: This research received no external funding

Acknowledgments: The authors would like to thank Island Grove Ag Products for allowing using their field picture, and Lauren Scott for her help in revising grammar errors.

Conflicts of Interest: The authors declare no conflict of interest.

\section{References}

1. Brazelton, C.; Fain, C.; Aragon, L.; Bauer, N. IBO 2019 State of the Blueberry Industry Report. International Blueberry Organization. 2019. Available online: https://www.internationalblueberry.org/downloads/onlinevisualization/ (accessed on 9 October 2020).

2. Banados, M.P. Expanding blueberry production into non-traditional production areas: Northern Chile and Argentina, Mexico and Spain. Acta Hortic. 2009, 810, 439-444. [CrossRef]

3. Finn, C.E.; Hancock, J.F.; Olmstead, J.W.; Brazelton, D.M. Welcome to the party! blueberry breeding mixes private and public with traditional and molecular to create a vibrant new cocktail. Acta Hortic. 2014, 1017, 51-62. [CrossRef]

4. Rematales, J.B.; Hancock, J.F. Blueberries, 2nd ed.; CABI Publishing: Wallingford, UK, 2018; ISBN 9781780647272.

5. Demchak, K. Small fruit production in high tunnels. Horttechnology 2009, 19, 44-49. [CrossRef]

6. Kadir, S.; Carey, E.; Ennahli, S. Influence of high tunnel and field conditions on strawberry growth and development. HortScience 2006, 41, 329-335. [CrossRef]

7. Thompson, E.; Strik, B.C.; Finn, C.E.; Zhao, Y.; Clark, J.R. High tunnel versus open field: Management of primocane-fruiting blackberry using pruning and tipping to increase yield and extend the fruiting season. HortScience 2009, 44, 1581-1587. [CrossRef]

8. Heidenreich, C.; Pritts, M.; Demchak, K.; Hanson, E. High Tunnel Raspberries and Blackberries; Cornell University Department of Horticulture: Ithaca, NY, USA, 2012; Volume 17, pp. 13-16.

9. Lamont, W.J; Orzolek, M.D.; Holcomb, E.J.; Demchak, K.; Burkhart, E.; White, L.; Dye, B. Production system for horticultural crops grown in the Penn State High Tunnel. Horttechnology 2003, 13, 358-362. [CrossRef]

10. Lang, G.A. High tunnel tree fruit production: The final frontier? Horttechnology 2009, 19, 50-55. [CrossRef]

11. Tamada, T.; Ozeki, M. Evaluation of blueberry types and cultivars for early market production in Japan using unheated plastic house culture. Int. J. Fruit Sci. 2012, 12, 83-91. [CrossRef]

12. Ciordia, M.; Díaz, M.B.; García, J.C. Blueberry culture both in pots and under Italian-type tunnels. Acta Hortic. 2002, 123-127. [CrossRef]

13. Baptista, M.C.; Oliveira, P.B.; Lopes-Da-Fonseca, L.; Oliveira, C.M. Early ripening of southern highbush blueberries under mild winter conditions. Acta Hortic. 2006, 715, 191-196. [CrossRef]

14. Ogden, A.B.; van Iersel, M.W. Southern highbush blueberry production in high tunnels: Temperatures, development, yield, and fruit quality during the establishment years. HortScience 2009, 44, 1850-1856. [CrossRef]

15. Reiss, E.; Both, A.J.; Garrison, S.; Kline, W.; Sudal, J. Season extension for tomato production using high tunnels. Acta Hortic. 2004, 659, 153-160. [CrossRef]

16. Santos, B.M.; Salame-Donoso, T.P. Performance of southern highbush blueberry cultivars under high tunnels in Florida. Horttechnology 2012, 22, 700-704. [CrossRef]

17. Gough, R.E. The Highbush Blueberry and Its Management; CRC Press: Boca Raton, FL, USA, 1993.

18. Barrau, C.; De Los Santos, B.; Calvo, D.; Medina, J.J.; Molina, J.M.; Romero, F. Low chilling blueberries (Vaccinium spp.) studies in Huelva (Andalusia, SW Spain): Present and future. Acta Hortic. 2004, 649, 305-308. [CrossRef] 
19. Li, T.; Bi, G. Container production of southern highbush blueberries using high tunnels. HortScience 2019, 54, 267-274. [CrossRef]

20. Darnell, R.L.; Williamson, J.G. Feasibility of blueberry production in warm climates. Acta Hortic. 1997, 446, 251-256. [CrossRef]

21. Williamson, J.G.; Darnell, R.L.; Krewer, G.; NeSmith, S. Effect of GA3 bloom sprays on fruit set and yield of rabbiteye blueberry. HortScience 1995, 30, 853. [CrossRef]

22. Moon, J.W., Jr.; Hancock, J.F., Jr.; Draper, A.D.; Flore, J.A. Genotypic differences in the effect of temperature on CO2 assimilation and water use efficiency in blueberry. J. Am. Soc. Hortic. Sci. 1987, 112, 170-173.

23. Krewer, G.; Ruter, J. Fertilizing highbush blueberries in pine bark beds (Bulletin 1291). Univ. Georg. Coop. Estension 2009. Available online: https://athenaeum.libs.uga.edu/bitstream/handle/10724/12290/B1291.pdf? sequence $=1$ \&isAllowed $=y$ (accessed on 9 October 2020).

24. Williamson, J.G.; Lyrene, P.M.; Olmstead, J.W. Protecting blueberries from freezes in Florida. Univ. Fla. Inst. Food Agric. Sci. 2012, 1-7.

25. Abou-Shaara, H.F.; Owayss, A.A.; Ibrahim, Y.Y.; Basuny, N.K. A review of impacts of temperature and relative humidity on various activities of honey bees. Insectes Soc. 2017, 64, 455-463. [CrossRef]

26. Chavez, D.J.; Lyrene, P.M. Interspecific crosses and backcrosses between diploid vaccinium darrowii and tetraploid southern highbush blueberry. J. Am. Soc. Hortic. Sci. 2009, 134, 273-280. [CrossRef]

27. Taber, S.K.; Olmstead, J.W. Impact of cross- and self-pollination on fruit set, fruit size, seed number, and harvest timing among 13 southern highbush blueberry cultivars. Horttechnology 2016, 26, 213-219. [CrossRef]

28. NeSmith, D.S. Use of plant growth regulators in blueberry production in the southeastern U.S. Int. J. Fruit Sci. 2005, 5, 41-54. [CrossRef]

29. Cho, H.Y.; Kadowaki, M.; Che, J.; Takahashi, S.; Horiuchi, N.; Ogiwara, I. Influence of light quality on flowering characteristics, potential for year-round fruit production and fruit quality of blueberry in a plant factory. Fruits 2019, 74, 3-10. [CrossRef]

30. Aung, T.; Muramatsu, Y.; Horiuchi, N.; Che, J.; Mochizuki, Y.; Ogiwara, I. Plant growth and fruit quality of blueberry in a controlled room under artificial light. J. Jpn. Soc. Hortic. Sci. 2014, 83, 273-281. [CrossRef]

31. Spann, T.M.; Williamson, J.G.; Darnell, R.L. Photoperiodic effects on vegetative and reproductive growth of Vaccinium darrowi and V. corymbosum interspecific hybrids. HortScience 2003, 38, 192-195. [CrossRef]

32. Spiers, J.M. Substrate temperatures influence root and shoot growth of southern highbush and rabbiteye blueberries. HortScience 1995, 30, 1029-1030. [CrossRef]

33. Motomura, S.; Cho, A.; Hamasaki, R.; Akahoshi, K.; Kawabata, A.; Kawabata, A.; Nakamoto, S. Evaluation of pot size for greenhouse production of 'Misty' southern highbush blueberry in Volcano, Hawai'i. Fruit Nut. Beverage Crop. 2016, 1-4.

34. Kameari, N.; Horiuchi, N.; Suzuki, S.; Koike, H.; Ogiwara, I. Photosynthetic characteristics of highbush blueberry and rabbiteye blueberry in phytotron. Hortic. Res. 2010, 9, 455-460. [CrossRef]

35. Spann, T.M.; Williamson, J.G.; Darnell, R.L. Photoperiod and temperature effects on growth and carbohydrate storage in southern highbush blueberry interspecific hybrid. J. Am. Soc. Hortic. Sci. 2004, 129, $294-298$. [CrossRef]

36. Gaskell, M. Yield and fruit quality of southern highbush blueberries at varying planting density and row spacing. Acta Hortic. 2009, 810, 489-494. [CrossRef]

37. Strik, B.; Buller, G. Improving yield and machine harvest efficiency of "Bluecrop" through high density planting and trellising. Acta Hortic. 2002, 227-231. [CrossRef]

38. Bryla, D.R.; Strik, B.C. Effects of cultivar and plant spacing on the seasonal water requirements of highbush blueberry. J. Am. Soc. Hortic. Sci. 2007, 132, 270-277. [CrossRef]

39. Lyrene, P.M.; Williamson, J.G. High-density blueberry plantings in Florida. Acta Hortic. 1997, 446, $265-270$. [CrossRef]

40. Singerman, A.; Burani-Arouca, M.; Williamson, J.G.; England, G.K. Establishment and production costs for southern highbush blueberry orchards in Florida: Enterprise budget and profitability analysis. Univ. Fla. Inst. Food Agric. Sci. 2019, 1-14.

41. Fonsah, E.G.; Massonnat, J.; Wiggins, L.; Krewer, G.; Stanaland, D.; Smith, J.E. Southern highbush blueberry marketing and economics. Univ. Georg. Ext. 2016, 1413, 1-10.

42. Moore, J.N.; Brown, M.V.; Bordelon, B.P. Yield and fruit size of "Bluecrop" and "Blueray" highbush blueberries at three plant spacings. HortScience 1993, 28, 1162-1163. [CrossRef] 
43. Strik, B.; Buller, G. The impact of early cropping on subsequent growth and yield of highbush blueberry in the establishment years at two planting densities is cultivar dependant. HortScience 2005, 40, 1998-2001. [CrossRef]

44. Norden, D.E.; Straughn, A. Blueberry Plant Named “Patrecia”. Application Number 14/998937, 7 March 2017.

45. Lyrene, P.M. Blueberry Plant Called “Abundance". Application Number 10/871999, 25 April 2006.

46. Muneer, S.; Kim, J.H.; Park, J.G.; Shin, M.H.; Cha, G.H.; Kim, H.L.; Ban, T.; Kumarihami, H.M.P.C.; Kim, S.H.; Jeong, G.; et al. Reflective plastic film mulches enhance light intensity, floral induction, and bioactive compounds in 'O'Neal' southern highbush blueberry. Sci. Hortic. (Amsterdam) 2019, 246, 448-452. [CrossRef]

47. Coventry, J.M.; Fisher, K.H.; Strommer, J.N.; Reynolds, A.G. Reflective mulch to enhance berry quality in Ontario wine grapes. Acta Hortic. 2005, 689, 95-102. [CrossRef]

48. Decoteau, D.R.; Kasperbauer, M.J.; Daniels, D.D.; Hunt, P.G. Plastic mulch color effects on reflected light and tomato plant growth. Sci. Hortic. (Amsterdam) 1988, 34, 169-175. [CrossRef]

49. Li, T.; Heuvelink, E.; Dueck, T.A.; Janse, J.; Gort, G.; Marcelis, L.F.M. Enhancement of crop photosynthesis by diffuse light: Quantifying the contributing factors. Ann. Bot. 2014, 114, 145-156. [CrossRef] [PubMed]

50. Paulitz, T.C.; Belanger, R.R. Biological control in greenhouse systems. Annu. Rev. Phytopathol. 2001, 39, 103-133. [CrossRef] [PubMed]

51. Phillips, D.A.; Flor, N.C.; Harmon, P.F. Florida blueberry leaf disease guide. Univ. Fla. Inst. Food Agric. Sci. 2019, 2019. [CrossRef]

52. Blomgren, T.; Frisch, T. High tunnels. Univ. Vermont Cent. Sustain. Agric. 2007, 107-116. [CrossRef]

53. VanEe, G.; Ledebuhr, R.; Hanson, E.; Hancock, J.; Ramsdell, D.C. Canopy development and spray deposition in highbush blueberry. Horttechnology 2000, 10, 353-359. [CrossRef]

54. Lyrene, P.M. Value of various taxa in breeding tetraploid blueberries in Florida. Euphytica 1997, 94, 15-22. [CrossRef]

55. Swain, P.A.W.; Darnell, R.L. Production systems influence source limitations to growth in "Sharpblue" southern highbush blueberry. J. Am. Soc. Hortic. Sci. 2002, 127, 409-414. [CrossRef]

56. Reeder, R.K.; Darnell, R.L.; Obreza, T.A. Establishment of an evergreen high density blueberry planting in southwest Florida. Proc. Fla. State Hort. Soc. 1994, 107, 326-328.

57. Lyrene, P. Breeding southern highbush blueberries. Plant Breed. Rev. 2008, 30, 353-414. [CrossRef]

58. Wright, G. Performance of southern highbush and rabbiteye blueberries on the corindi plateau N.S.W. Australia. Acta Hortic. 1993, 141-146. [CrossRef]

59. Hummer, K.; Zee, F.; Strauss, A.; Keith, L.; Nishijima, W. Evergreen production of southern highbush blueberries in Hawai'i. J. Am. Pomol. Soc. 2007, 61, 188-195.

60. Brazelton, C. World blueberry acreage \& production. N. Am. Blueberry Counc. 2013, 76.

61. Maatala, N.; Bekkar, Y.; El Hassnaoui, O.; Lebailly, P. Technical and economic efficiency of irrigation water use for the farms of blueberry and raspberry in the loukkos area in Morocco. Int. J. Agric. Econ. 2020, 5, 1-8. [CrossRef]

62. Phillips, D.; Williamson, J.G. Nutrition and fertilization practices for southern highbush blueberry in Florida. Univ. Fla. Inst. Food Agric. Sci. 2020, 1-7. [CrossRef]

63. Swain, P.A.W.; Darnell, R.L. Differences in phenology and reserve carbohydrate concentrations between dormant and nondormant production systems in southern highbush blueberry. J. Am. Soc. Hortic. Sci. 2001, 126, 386-393. [CrossRef]

64. Lyrene, P.M. Early defoliation reduces flower bud counts on rabbiteye blueberry. HortScience 1992, 27, 783-785. [CrossRef]

65. Reeder, R.K.; Obreza, T.A.; Darnell, R.L. Establishment of a non-dormant blueberry (Vaccinium corymbosum hybrid) production system in a warm winter climate. J. Hortic. Sci. Biotechnol. 1998, 73, 655-663. [CrossRef]

66. Darnell, R.L. Photoperiod, carbon partitioning, and reproductive development in rabbiteye blueberry. J. Am. Soc. Hortic. Sci. 1991, 116, 856-860. [CrossRef]

67. Maust, B.E.; Williamson, J.G.; Darnell, R.L. Flower bud density affects vegetative and fruit development in field-grown southern highbush blueberry. HortScience 1999, 34, 607-610. [CrossRef]

68. Huang, S.H.; Li, K.T. Dormant season fertigation promotes photosynthesis, growth, and flowering of 'Blueshower' rabbiteye blueberry in warm climates. Hortic. Environ. Biotechnol. 2015, 56, 756-761. [CrossRef] 
69. Almutairi, K.F.; Bryla, D.R.; Strik, B.C. Potential of deficit irrigation, irrigation cutoffs, and crop thinning to maintain yield and fruit quality with less water in northern highbush blueberry. HortScience 2017, 52, 625-633. [CrossRef]

70. Sales, B.K.; Bryla, D.R.; Trippe, K.M.; Weiland, J.E.; Scagel, C.F.; Strik, B.C.; Sullivan, D.M. Amending sandy soil with biochar promotes plant growth and root colonization by mycorrhizal fungi in highbush blueberry. HortScience 2020, 55, 353-361. [CrossRef]

71. Williamson, J.G.; Lyrene, P.M.; Olmstead, J.W. Florida's commercial blueberry industry. H2742. Gainesv. Univ. Fla. Inst. Food Agric. Sci. 2018, 1-4.

72. Voogt, W.; Van Dijk, P.; Douven, F.; Van Der Maas, R. Development of a soilless growing system for blueberries (vaccinium corymbosum): Nutrient demand and nutrient solution. Acta Hortic. 2014, 1017, 215-221. [CrossRef]

73. Olympios, C.M. Overview of soilless culture: Advantages, constraints and perspectives for its use in Mediterranean countries. Cah. Options Méditerranéennes 1999, 31, 307-324.

74. Whidden, A. Commercial blueberry production methods in Hillsborough County. Proc. Fla. State Hort. Soc. 2008, 121, 36-37.

75. Wilber, W.L.; Williamson, J.G. Effects of fertilizer rate on growth and fruiting of containerized southern highbush blueberry. HortScience 2008, 43, 143-145. [CrossRef]

76. Yaeger, T.; Fare, D.; Lea-Cox, J.; Ruter, J.; Bilderback, T.; Gilliam, C. Best Management Practices: Guide for Producing Container-Grown Plants; Southern Nursery Association: Marietta, GA, USA, 2007; pp. 1-7.

77. Poorter, H.; Bühler, J.; Van Dusschoten, D.; Climent, J.; Postma, J.A. Pot size matters: A meta-analysis of the effects of rooting volume on plant growth. Funct. Plant. Biol. 2012, 39, 839-850. [CrossRef]

78. Cantliffe, D.J. Pre- and postharvest practices for improved vegetable transplant quality. Horttechnology 1993, 3, 415-416. [CrossRef]

79. Passioura, J.B. Viewpoint: The perils of pot experiments. Funct. Plant. Biol. 2006, 33, 1075-1079. [CrossRef] [PubMed]

80. Owen, J.S.; Altland, J.E. Container height and douglas fir bark texture affect substrate physical properties. HortScience 2008, 43, 505-508. [CrossRef]

81. Kang, S.; van Iersel, M.W.; Kim, J. Plant root growth affects FDR soil moisture sensor calibration. Sci. Hortic. (Amsterdam) 2019, 252, 208-211. [CrossRef]

82. Hung, C.D.; Hong, C.H.; Kim, S.K.; Lee, K.H.; Park, J.Y.; Nam, M.W.; Choi, D.H.; Lee, H.I. LED light for in vitro and ex vitro efficient growth of economically important highbush blueberry (Vaccinium corymbosum L.). Acta Physiol. Plant. 2016, 38. [CrossRef]

83. Nunez, G.H.; Harmon, C.L.; Olmstead, J.W.; Darnell, R.L. Root-level inoculation with iron-reducing microorganisms does not enhance iron uptake by southern highbush blueberry plants. Rhizosphere 2016, 2, 24-33. [CrossRef]

84. Poonnachit, U.; Darnell, R. Effect of ammonium and nitrate on ferric chelate reductase and nitrate reductase in Vaccinium species. Ann. Bot. 2004, 93, 399-405. [CrossRef]

85. Raviv, M.; Wallach, R.; Silber, A.; Bar-Tal, A.; Raviv, M.; Wallach, R.; Silber, A.; Bar-Tal, A. Substrates and their analysis. Hydroponic Prod. Vegtables Ornamentals 2002, 25-105.

86. Kingston, P.H.; Scagel, C.F.; Bryla, D.R. Suitability of sphagnum moss, coir, and douglas fir bark as soilless substrates for container production of highbush blueberry. HortScience 2017, 52, 1692-1699. [CrossRef]

87. Kingston, P.H.; Scagel, C.F.; Bryla, D.R.; Strik, B.C. Influence of perlite in peat- and coir-based media on vegetative growth and mineral nutrition of highbush blueberry. HortScience 2020, 55, 1-6. [CrossRef]

88. Odneal, M.B.; Kaps, M.L. Fresh and aged pine bark as soil amendments for establishment of highbush blueberry. HortScience 1990, 25, 1228-1229. [CrossRef]

89. Scagel, C.F. Growth and nutrient use of ericaceous plants grown in media amended with sphagnum moss peat or coir dust. HortScience 2003, 38, 46-54. [CrossRef]

90. Ameri, A.; Tehranifar, A.; Davarynejad, G.H.; Shoor, M. The effects of substrate and cultivar in quality of strawberry. J. Biol. Environ. Sci. 2012, 6, 181-188.

91. Hanna, H.Y. Influence of cultivar, growing media, and cluster pruning on greenhouse tomato yield and fruit quality. Horttechnology 2009, 19, 395-399. [CrossRef]

92. Murray, J.D.; Lea-Cox, J.D.; Ross, D.S. Time domain reflectometry accurately monitors and controls irrigation water applications in soilless substrates. Acta Hortic. 2004, 633, 75-82. [CrossRef] 
93. Lemay, I.; Caron, J.; Dorais, M.; Pepin, S. Defining irrigation set points based on substrate properties for variable irrigation and constant matric potential devices in greenhouse tomato. HortScience 2012, 47, 1141-1152. [CrossRef]

94. Evans, M.R.; Konduru, S.; Stamps, R.H. Source variation in physical and chemical properties of coconut coir dust. HortScience 1996, 31, 965-967. [CrossRef]

95. Asănică, A. Estimation of the economic efficiency of blueberry according to the production system. Sciendo 2018, 1, 255-259. [CrossRef]

96. Grieshop, M.; Gut, L.; Wise, J.; Smith, P.O.; Sundin, G.; Miller, S.; Flore, J.; Lang, G.; Perry, R. Development of solid set delivery systems for high density apples. N. Y. Fruit Q. 2015, 32, 16-20.

97. Million, J.B.; Yeager, T.H. Testing an automated irrigation system based on leaching fraction testing and weather in a container nursery. Horttechnology 2019, 29, 114-121. [CrossRef]

(C) 2020 by the authors. Licensee MDPI, Basel, Switzerland. This article is an open access article distributed under the terms and conditions of the Creative Commons Attribution (CC BY) license (http://creativecommons.org/licenses/by/4.0/). 